\title{
Republic of Moldova: Report on the Observance of Standards and Codes- Fiscal Transparency Module
}

This Report on the Observance of Standards and Codes on Fiscal Transparency for the Republic of Moldova was prepared by a staff team of the International Monetary Fund as background documentation for the periodic consultation with the member country. It is based on the information available at the time it was completed on December 1, 2004. The views expressed in this document are those of the staff team and do not necessarily reflect the views of the government of the Republic of Moldova or the Executive Board of the IMF.

The policy of publication of staff reports and other documents by the IMF allows for the deletion of market-sensitive information.

To assist the IMF in evaluating the publication policy, reader comments are invited and may be sent by e-mail to publicationpolicy@imf.org.

\author{
Copies of this report are available to the public from \\ International Monetary Fund • Publication Services \\ 700 19th Street, N.W. • Washington, D.C. 20431 \\ Telephone: (202) 6237430 • Telefax: (202) 6237201 \\ E-mail: publications@imf.org • Internet: http://www.imf.org \\ Price: $\$ 15.00$ a copy

\section{International Monetary Fund \\ Washington, D.C.}





\title{
INTERNATIONAL MONETARY FUND
}

\section{REPUBLIC OF MOLDOVA}

\section{Report on the Observance of Standards and Codes (ROSC) Fiscal Transparency Module}

\author{
Prepared by the Fiscal Affairs Department \\ Approved by Michael C. Deppler and Teresa Ter-Minassian
}

December 1, 2004

\section{EXECUTIVE SUMMARY}

This report provides an assessment of fiscal transparency practices in Moldova in relation to the requirements of the IMF Code of Good Practices on Fiscal Transparency based on discussions with the authorities and others, the authorities' response to the IMF fiscal transparency questionnaire, and other sources. The IMF Manual on Fiscal Transparency (http://www.imf.org/external/np/fad/trans/manual) should be consulted for further explanation of the terms and concepts discussed in this report.

Moldova has made progress in recent years in improving fiscal transparency and meets the Code of Good Practices on Fiscal Transparency in some areas. However, shortcomings remain in several areas and key weaknesses have been identified in the monitoring of state-owned enterprises and the regulatory framework for the private sector. Moldova has also made progress in recent years in fiscal transparency in defining the roles and responsibilities of the executive, legislative, and judiciary, and the separation of government activities from those of the central bank and financial sector institutions. The quality of budget preparation has improved considerably over the past few years, in particular reflecting the introduction of medium-term expenditure frameworks (MTEFs). In this area, the Ministry of Finance has recently made commendable progress. Reporting on budget execution has also improved, and disclosure of final annual accounts is timely.

In a range of other areas, Moldova meets fiscal transparency requirements to some extent, but further improvements would be useful. The coordination mechanisms between budget and off-budget activities are formally rather well defined, but social funds, extrabudgetary funds, and donor-financed projects should be fully integrated into the central government budget. The relations between central and local governments should be put on a sounder and more stable footing, following more intensive consultations between the State and local governments. As a result of recent reforms, quasi-fiscal activities and contingent liabilities in the energy sector have declined in importance in recent years, but they remain sizable, requiring further scrutiny and policy attention.

The provision of data and information to the general public should be strengthened further, for example through more detailed and comprehensive monthly reporting. The central government should intensify efforts to prepare and monitor the budget on a general government basis. The consolidation of tax legislation into two organic codes (domestic taxes and customs) has improved transparency, but the authorities should refrain from too frequent amendments to these codes, including during budget execution. Modernizing and consolidating treasury operations is a matter of urgency, as are reforms in internal control and external audit. Corruption continues to be perceived as a key problem by businesses, donors, and others, notwithstanding the intensified efforts of the authorities to reduce it. Fiscal transparency should be improved in particular in those areas in which key weaknesses have been identified. Notably, the monitoring of state-owned enterprise finances requires strengthening and the activities of line ministries and state-owned enterprises should be better distinguished. While the legal and regulatory framework for private sector activities is formally clear and well specified, transparency has suffered in recent years due to the introduction of informal restrictions. 



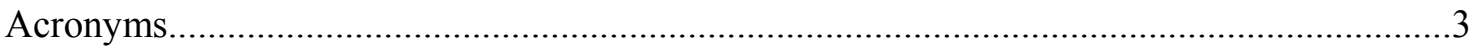

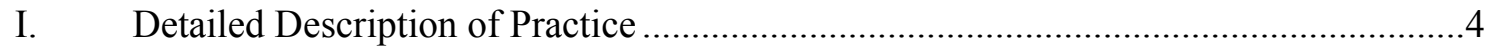

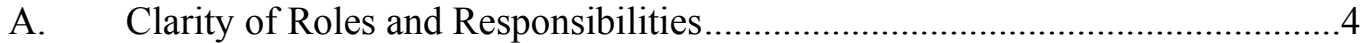

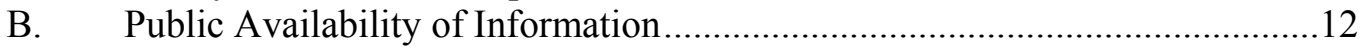

C. Open Budget Preparation, Execution, and Reporting ..................................16

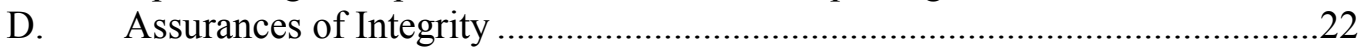

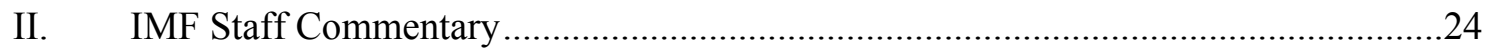

Boxes

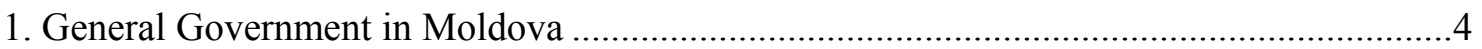

2. Local Government in Moldova ................................................................................ 9

3. Energy Sector Quasi-Fiscal Activities and Contingent Liabilities ...................................15

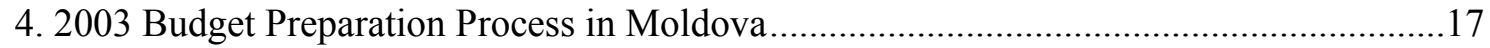

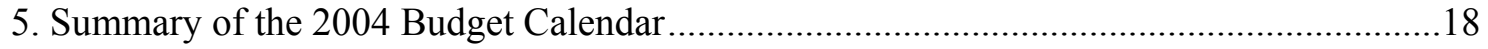

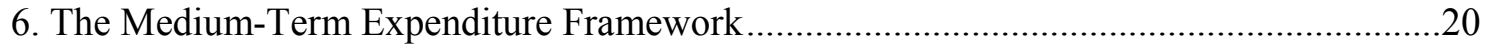

Appendices

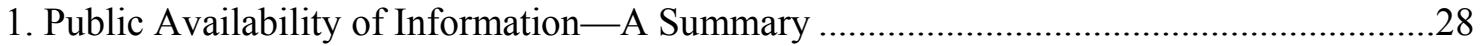


ACRONYMS

$\begin{array}{ll}\text { CFAA } & \text { Country Financial Accountability Assessment } \\ \text { CG } & \text { Central Government } \\ \text { COA } & \text { Court of Accounts } \\ \text { DFID } & \text { Department for International Development } \\ \text { EBFs } & \text { Extrabudgetary Funds } \\ \text { EBRD } & \text { European Bank for Reconstruction and Development } \\ \text { FCAD } & \text { Financial Control and Audit Department } \\ \text { GDDS } & \text { General Data Dissemination Standard } \\ \text { GFS } & \text { Government Finance Statistics } \\ \text { HIF } & \text { Health Insurance Fund } \\ \text { MoE } & \text { Ministry of Economy } \\ \text { MoF } & \text { Ministry of Finance } \\ \text { MTEF } & \text { Medium-Term Expenditure Framework } \\ \text { NBM } & \text { National Bank of Moldova } \\ \text { NSIF } & \text { National Social Insurance Fund } \\ \text { PRSP } & \text { Poverty Reduction Strategy Paper } \\ \text { ROSC } & \text { Reports on the Observance of Standards and Codes } \\ \text { SDDS } & \text { Special Data Dissemination Standard } \\ \text { SOE } & \text { State-owned enterprise } \\ \text { STI } & \text { State Tax Inspectorate }\end{array}$




\section{Detailed Description of Practice ${ }^{1}$}

\section{A. Clarity of Roles and Responsibilities}

Definition of Government Activities

1. General government is largely defined in consistency with Government Finance Statistics (GFS) principles, but not yet fully covered in the budget process. A two-tier structure of government exists (central and local governments), and the authorities use a number of different budget definitions, including the State budget, the Consolidated Budget, and a broader definition ("The National Public Budget") which resembles that of general government. The central government consists of the State budget, the National Social Insurance Fund (NSIF), the Health Insurance Fund (HIF), and 12 Extrabudgetary Funds (EBFs). The Consolidated Budget includes the State and local government budgets (Box 1).

\begin{tabular}{|lcc|}
\hline \multicolumn{2}{|c|}{ Box 1. General Government Budget in Moldova, 2003 } \\
& In MDL & In Percent of \\
& GDP \\
Stage Budget & Millions & 15.6 \\
Consolidated Budget = State budget + local government budgets & 4,251 & 25.8 \\
$\begin{array}{l}\text { Central government budget 1/ = State budget + National Social } \\
\text { Insurance Fund (NSIF) budget + 12 Extrabudgetary Funds }\end{array}$ & 7,039 \\
$\begin{array}{l}\text { General government budget ("National Public Budget") = central } \\
\text { government budget + local government budgets }\end{array}$ & 6,518 \\
$\begin{array}{l}\text { 1/ The Health Insurance Fund budget (fully operational from January1, 2004) will in future also be } \\
\text { included in this definition. }\end{array}$ & 34.1 \\
\hline
\end{tabular}

2. The budget of the general government includes the central government and the local governments. Local governments include two levels - regions (including special areas), and communes and municipalities (paragraph 11 and Box 2). Transnistria is not included as part of the general government as it is not subordinated to the Republic of Moldova. The Law on the Budgetary System and the Budgetary Process, No. 847XIII/1996 (hence organic budget law) and the annual State budget laws define the revenue sharing system for key taxes (e.g., VAT, income tax) between the State and local

\footnotetext{
${ }^{1}$ Discussion on fiscal transparency were held in Chisinau during January 26-February 6, 2004. The staff team, comprising Ms. Jacobs and Messrs. Ganelli and Taube (all FAD), was supported by the IMF Resident Representative, Mr. Ruggiero, and Mr. Scerbatchi, Research Assistant in the IMF office in Moldova. The team met with Finance Minister Grecianîi, officials from various government ministries and departments, as well as representatives of parliament, state-owned enterprises, donors, NGOs, and the business community.
} 
governments. Local governments can also raise own revenues. Transfers to local governments are approved by parliament as part of the State budget. EBFs are included in the annual State budget as separate annexes which are approved together with the State budget by parliament. The budgets of the NSIF and the HIF are prepared and approved independently from the State budget. This separation makes it difficult to present a general government budget and monitor its execution during the fiscal year. The Ministry of Finance (MoF) provides to the President's Office and the legislature monthly reports on the execution of the Consolidated Budget; information on the execution of the NSIF and HIF budgets is provided separately. The definition of government activity is consistent between the MoF and the central bank (National Bank of Moldova, NBM). The discrepancy between above-the-line (revenue minus expenditure) and below-the line (domestic and external financing) fiscal data has been reduced significantly to a relatively small amount (0.3 percent of GDP in 2003).

\section{The relationships between government and state-owned enterprises $\quad 1.1 .4$} (SOEs) are legally well defined, but not easily distinguishable. No centralized monitoring of SOE financial performance exists. Nonfinancial state-owned enterprises (SOEs) are supervised by line ministries. Activities of line ministries and these enterprises are legally well defined, ${ }^{2}$ but in practice not easy to distinguish. The financial operations of SOEs are not monitored by any central government agency. Hence there is no systematic and comprehensive reporting on SOE finances to the government, parliament, and the general public. ${ }^{3}$ Some SOEs receive explicit subsidies from the State and local government budgets for providing goods and services to the public (e.g., children's publications, transport services for pensioners).

4. Government holdings of fully-owned corporations and equity have 1.1.5/2.1.4 declined, but remain sizable. Data on government equity holdings are recorded by the MoF 4 line ministries, the Department of Privatization, and local governments. These data are available on request, but published only partially, as in the case of enterprises slated for privatization. No financial corporation is entirely publicly owned, but the State possesses 56 percent of the shares of one of the largest banks, the Banca de Economii S.A. The Department of Privatization has 482 SOEs on its privatization list, including joint stock companies and other enterprises with government ownership. ${ }^{4}$ Little information is publicly available about local government ownership of companies.

\footnotetext{
${ }^{2}$ See the Law on Enterprises and Entrepreneurship (No. 845-XII, 1992), amended by Law No. 1167 of 1997.

${ }^{3}$ There is, however, periodic reporting by SOEs to the Department of Statistics and Sociology. Also, SOEs are subject to the same standard reporting requirements vis-à-vis tax authorities as other enterprises.

${ }^{4}$ The vast majority of SOEs are joint stock companies. The State holds equity in 442 such companies. Of these 6 percent are fully owned by the State, in 17 percent of them the State ownership accounts for up to 5 percent; in 4 percent it owns 5 to 10 percent; in 9 percent it owns 10 to 25 percent; in 14.5 percent it possesses 25 to 50 percent; in 49 percent the State share is 50 to 100 percent.
} 
$\underline{\text { Government relations with nonfinancial public corporations and the private sector }}$

5. Quasi-fiscal activities of public nonfinancial corporations have

1.1.4 declined significantly in recent years, but they are still sizable in the energy sector. In the transport, water, and energy sectors, fully or partially government-owned enterprises dominate and carry out quasi-fiscal activities. In the energy sector, these activities have declined significantly in recent years following reforms in the electricity subsector, but they remain sizable in the gas subsector (paragraph 27 and Box 3).

6. Arrangements regulating dividends from SOEs to the State budget are 1.1 .4 de jure clearly regulated. In general, SOE dividends are transferred to the State budget as prescribed by relevant laws and regulations, and depending on shareholder decisions on profit distribution. De facto, however, only small amounts of dividends have been transferred to the State budget in recent years (e.g., Mdl 5 million in 2003).

7. The legal framework for privatization and the use of privatization 1.1 .5 proceeds is relatively clear, but the privatization process is complex. Privatization is carried out under two privatization laws and a number of regulations. ${ }^{5}$ In cooperation with line ministries, the Department of Privatization is in charge of privatizing the State's share in 482 enterprises. The Department executes the annual privatization program, which is drawn up in consultation with line ministries; it is supposed to be published at the beginning of each fiscal year. However, the 2003 program was officially approved and published only by mid-year. Sales of stakes in joint stock companies are usually carried out through open tenders with the help of consulting companies. The privatization of 12 strategic companies is done under the auspices of the Prime Minister's Office through direct sales or tenders. The accounting of privatization proceeds is transparentall proceeds are handed over to the Treasury and used for budget financing; with proceeds from the sales of strategic enterprises used to repay government debt. If local governments own part of the equity of sold enterprises, their share of privatization proceeds is handed over to them.

8. Laws and processes regulating the nonfinancial private sector are $\quad 1.1 .5$ formally well defined, but the inspection system remains pervasive and informal restrictions have been introduced. Government regulations of nonfinancial sectors are generally spelled out clearly and comprehensively in various laws, including the Law on Property Ownership, the Law on Entrepreneurial Activity and Enterprises, and the Law on Joint Stock Companies. Licensing and business registration procedures have been streamlined in recent years, which has improved transparency; however, a pervasive system of inspections on national standards, sanitary authorizations, and other certificates remains in place. Additional inspections to record irregularities as part of criminal prosecution are carried out by the Center for Combating Corruption and Economic Crime, which employs the former staff of the financial guards. Prices, tariffs, and fees in a number of sectors (e.g., energy, heating, transport, water, education, and health) are administratively determined by national regulatory agencies, government organizations,

\footnotetext{
${ }^{5}$ Privatization Law No. 627-XII of July 1991, and Law on 1997-98 Privatization Program No. 1217-XIII of June 1997, as amended and valid until December 31, 2005.
} 
and local governments. Recently, the government has introduced informal restrictions on the exports of certain products (e.g., sunflower seeds, wheat, scrap metal), which has reduced the transparency of the regulatory framework.

$\underline{\text { Government relations with the central bank and public financial sector }}$

9. The central bank is formally independent and currently does not carry out quasi-fiscal activities. The primary objective of the central bank (NBM), according to Law No. 548-XIII/1995, is to "achieve and maintain the stability of the national currency." Articles 37-43 of this Law describe the relationship between the NBM and the government, including its role as the banker and fiscal agent of the government. The NBM organizes treasury bill auctions, and maintains the single treasury account for the government. There is an adequate legal basis in place regulating the transfer of NBM net income to the budget, and NBM net income transferred is shown transparently in the annual budget and budget execution reports. The NBM's role in financing of the budget deficit is clearly spelt out in the law mentioned above. The NBM does not currently carry out any quasi-fiscal activities. ${ }^{6}$

10. Public financial corporations carry out limited quasi-fiscal activities in 1.1 .4 a few areas. The government controls one commercial bank (paragraph 3); and it generally does not interfere with the operations of banks and other financial sector participants. All financial institutions are subject to supervision by the NBM as spelt out in Article 44 of the NBM Law. Quasi-fiscal activities with limited costs have been identified in two areas: (1) following an open tender the NSIF decided in 2003 to place deposits, which form part of its Reserve Fund, in the Banca de Economii at a belowmarket interest rate; (2) several years ago, banks were required to provide long-term loans for housing at below-market interest rates. However, the losses incurred by banks from these old loans are now regularly offset by transfers from the State budget, which are explicitly presented in the annual budget and budget execution reports. No new loans under this program are currently provided by the NBM.

$\underline{\text { Fiscal management relations among the branches of government }}$

11. The fiscal roles of the executive, legislative and judicial branches are 1.1 .2 clearly defined in the Constitution and relevant laws. The Constitution and the Law on Government ${ }^{7}$ give a clear description of executive, legislative, and judicial functions. The Constitution (Chapter IV) sets out the relations between parliament and government. Parliament approves the State budget, and the budgets of the NSIF, the HIF, and EBFs. According to the organic budget law, ${ }^{8}$ if the budget law is not approved by the start of the fiscal year, monthly provisions, equal to ${ }^{1} / 12$ of the authorized budget of the previous year, are allocated. Before presentation to parliament, the draft of the annual budget is analyzed and discussed by an advisory committee under the Prime Minister, comprising

\footnotetext{
6 This is prohibited by article 71 of the Law on the National Bank of Moldova, Law No. 548-XIII/1995.

${ }^{7}$ Law No. 589-XII/1991.

${ }^{8}$ Law on the Budgetary System and the Budgetary Process, No. 847-XIII/1996.
} 
representatives of employers, trade unions, professional associations, the scientific community, and civil society.

$\underline{\text { Fiscal management relations among different levels of government }}$

12. The responsibilities of different levels of government are well defined, $\quad 1.1 .2$ but subject to frequent changes. The division of responsibilities between State and local governments and the rules for the preparation and execution of local government budgets are broadly defined in the Constitution, local government laws (e.g., Law on Local Public Finance, No. 397-XV/2003), and the annual State budget. Two administrative-territorial reforms and other changes to local government finances have caused considerable uncertainty and reduced transparency, in particular as these have coincided with changes in revenue sharing arrangements, expenditure functions, and transfer formulae from one budget year to the next. The latest administrative-territorial change became effective in March 2003, when the concept of regions (rayons) was reintroduced (Box 2). The 2004 draft State budget provides information on revenue-sharing and transfer formulae, but according to local government representatives the revenue assignments do not appear to take sufficient account of local government needs and concerns. Local governments derive a large part of their revenue from major taxes that are administered by State tax administration. In addition, they collect revenue from own tax and nontax sources, and receive transfers from the State. The Law on Local Public Finance provides stringent rules on subnational borrowing.

The legal and administrative framework for budget management

13. The legal framework for management of public funds is generally

clear, but fragmented. Key principles for management of the State budget process are set forth in the organic budget law, ${ }^{9}$ the Law on Local Public Finance and the Law on State Debt and State Guarantees, No. 943-XIII/1996. The latter provides procedures and guidelines for issuing debt and guarantees, while the annual budget law establishes a ceiling on new public debt and government-guaranteed loans. The Tax Code (1997-2001) establishes tax rates and bases for domestic taxes. Customs duties are determined by the Law on Customs Tariffs (No. 1380-XIII/1997, and subsequent amendments. The Law on State Social Insurance, No. 489-XIV/1999, defines the scope and coverage of the NSIF. Gradual implementation of these laws has brought more stability and transparency into the fiscal system. The MoF plays a key role in fiscal management, and its role has been strengthened recently through various mechanisms, including the Medium Term Expenditure Framework (MTEF).

\footnotetext{
${ }^{9}$ Law on the Budgetary System and the Budgetary Process, No. 847-XIII/1996.
} 


\section{Box 2. Local Government in Moldova}

The Constitution (Articles 109-113) and relevant laws establish the concept of local autonomy of local governments, while generally describing their organization and functions, including the two-level local government structure. Within this general framework, two administrative-territorial reforms were implemented in 1999 and 2003 since independence. In 1999, the autonomy of local governments was strengthened, and a larger number of regions were consolidated into 10 larger units, called judets, plus one autonomous region (Gagauzia) and the Chisinau municipality. Below these, 43 towns and 593 communes were established. The March 2003 law reintroduced the concept of regions (rayons). The upper level of local government (in Moldova referred to as the "second level") now consists of 32 rayons as well as the autonomous region of Gagauzia and the two municipalities (Chisinau and Balti). The lower level (in Moldova referred to as the "first level") now comprises of 52 towns (cities) and 847 communes (villages). In the view of local government representatives and others, this reform as well as other recent changes to local government finances have tended to reduce the room for maneuver and interfered with local governments operations.

The organic budget law, the Law on Local Public Finance, and the annual State budget regulate the principles of revenue sharing arrangements and transfers between the State and the upper level of local government. In 2004, this level of local government receives 100 percent of corporate and personal income tax revenue, with the exception of Chisinau and Balti municipalities which are entitled to only 50 percent of such proceeds collected in their areas. While the State government sets the maximum rates for local fees and the property tax, local governments are free to levy lower rates (Article 2 of the Law on Local Fees, No. 186-XIII/1994). The State government has introduced tax concessions for the personal and corporate profit tax that have tended to erode the tax base of local governments, although the State government has sought to offset revenue losses through higher transfers from the State budget. Customs, VAT, and excise tax revenue remains with the State government, with the exception of Gagauzia where VAT and excise revenue accrues fully to the local government. In 2003, local governments received a share in VAT proceeds. Revenue from the road tax is shared equally between the State and local governments throughout the country. In addition, each of the two local government levels have own tax and nontax revenue sources to finance spending. On average, own revenue accounts for about 30 percent of total resources of upper-level local government authorities. The upper-level local governments are free in allocating revenue and transfers to the lower-level local governments in accordance with the Law on Local Public Finance.

Expenditure transfers from the State vary across upper-level local governments, with the objective to reduce territorial disparities in service provision and living conditions. The distribution of transfers to upper-level local governments is transparently shown in the State budget. In addition, an annex to the State budget provides projections for total budgets of this level of local government as well as transfers from the upper level to the lower level of local government. These are formally determined in a similar fashion as the transfers from the State to the upper-level local governments (Article 10, Law No. 397-XV/2003).

However, according to local government representatives, de facto the functioning of the transfer mechanism from the upper to the lower level of local governments appears to be subject to undue discretion. In general, information on the distribution of budgets between the two levels of local governments, and data on budget execution broken down between the two levels, is not easily available.

Strict borrowing rules for local governments are prescribed by the Law on Local Public Finance (Articles 13 and 14). These have been effectively enforced by the State government to avoid that overall fiscal stability is undermined by local government borrowing. Local governments can borrow short-term from banks for cash management purposes; however, these loans need to be repaid within the fiscal year. Total outstanding debt and interest payments on such short-term lending cannot exceed five percent of own revenue during the fiscal year. In addition, local governments can borrow to finance capital investment, but the annual amount of such borrowing cannot exceed 20 percent of own revenue. Banks often require an endorsement from the State government before lending to local governments, but the State does not recognize these loans as contingent liabilities or guarantees. Local governments report to the State MoF on borrowing on a monthly basis. 
14. Mechanisms for the coordination and management of budgetary and 1.1.3 extrabudgetary activities are defined, but the increasing use of EBFs is problematic for fiscal management. The Law on the Budgetary System and the Budgetary Process, No. 847-XIII/1996, regulates the establishment of EBFs and special funds for foreign grants and loans. Line ministries have established an increasing number of EBFs in recent years, which has made fiscal management more difficult. EBFs are only partially consolidated with the State budget. Rules on the formation and on the allocation of EBF resources are detailed in specific laws. EBFs of the State government are cash funds administered by the relevant authorized line ministries, and as a rule they are not independent institutional units. In accordance with the organic budget law, government institutions have the right to determine the utilization of extrabudgetary resources received from providing services for a fee, as well as direct grants, if so permitted under legislative and other regulatory acts. Some of these revenues are earmarked for EBFs, such as road fee proceeds for the Road Fund. EBFs are included in the annual budget in separate annexes. The draft State budget and budget execution reports include all financial resources controlled by government organizations and channeled through EBFs; these operations are part of the State treasury and data on EBF budget execution are included in the standard regular reports that the MoF provides to the government and parliament. Reporting on EBF activities to the general public is limited to references in the monthly summaries published by the MoF. EBFs are subject to separate accounting, reporting, and auditing practices, which are in line with standard government regulations.

\section{Foreign-financed investment projects are not well integrated into government} operations, which complicates monitoring and fiscal management. Investment projects financed by foreign loans and grants are generally implemented through project implementation units, which use special accounting and reporting mechanisms. These units (of which 10 currently exist) remain outside the treasury and the mainstream of general government operations, reflecting in part special requests from donors related to accounting and procurement practices. While these projects are included in a separate annex in the State budget, they are not consolidated with the State budget in the annual budget presentation and periodic budget reports. A pilot project is being prepared to include one World Bank loan-financed project into treasury operations.

\section{Government investment projects are not well coordinated or integrated with} the recurrent budget. Domestically financed investment projects and externally financed projects are not consolidated into the National Public Budget. Both types of projects are presented separately in annexes to the State budget. For domestically financed projects, the selection and prioritization criteria, including social goals, economic rates of return, and recurrent cost implications, are not transparently reported in the annual budget or elsewhere.

The legal and administrative framework for tax policy and administration

17. The legislative basis for taxation is comprehensive, but not always clear and unambiguous. The tax and customs codes provide the legal basis for tax liabilities and concessions for all major tax categories. Tax laws and regulatory acts are generally accessible, including in English language, and understandable. In some articles, however, the application of laws is difficult due to the complexity of language, allowing multiple interpretations of their substance. Major tax policy changes are generally introduced 
together with the draft annual State budget, but changes (mostly exemptions) are also made during the fiscal year on an ad hoc basis. Self-assessment is a statutory requirement. Taxes with specific rates are not automatically indexed to inflation, but adjusted in the annual State budget.

\section{Tax exemptions are extensive and tax expenditures are only reported in} aggregate terms in the draft State budget. Nonstandard tax exemptions from direct and indirect taxes are extensive, causing considerable costs to the government. For example, in 2002 the cost of all (i.e., including standard) VAT exemptions was estimated by the MoF at about Mdl 700 million (3 percent of GDP). Aggregate estimates of tax expenditures are reported to parliament and included in the explanatory notes of the draft budget (paragraph 26).

19. Transparency in tax and customs administration needs further. improvements. Title V of the Tax Code, which became effective in July 2002, defines the legal framework for the activities of the State Tax Inspectorate (STI), which reports to the MoF. It also specifies the enforcement powers of tax officials. The administrative setup of the STI has been modernized in recent years; it is now functionally organized, with enforcement, audit, and appeals departments, as well as a Large Taxpayer Unit. The use of Taxpayer Identification Numbers by the tax and customs administration, as well as the establishment of modern enforcement methods (e.g., seizure of taxpayer assets kept by third parties) have helped improving transparency. The degree of discretion that the tax and customs codes grant to tax officials in requesting information from, and in releasing information to, third parties is considerable. The staff of the former financial guards, now employed by the Center for Combating Economic Crime and Corruption, can undertake inspections and audits independently from the tax and customs administrations for purposes of documenting violations as part of activities for criminal prosecution.

20. The tax and customs legislation clearly specify taxpayers' legal rights 1.2.2 and obligations, including the right to appeal; however these rights are not strong. The Tax Code specifies the procedure available to the taxpayer to appeal against decisions of tax authorities and actions of tax officials. Complaints must be filed first with the local tax offices. A ruling by a local tax office on a complaint can be appealed by a taxpayer at the level of the Main State Tax Inspectorate or relevant judicial authority (Article 269 of the Tax Code). In the area of VAT administration, the tax authorities have recently observed more fraud, while taxpayers appear to be increasingly concerned about excessively bureaucratic procedures in the refund application process. ${ }^{10}$ The STI has made efforts to improve taxpayer information; these include the establishment of Taxpayers Assistance Offices and workshops to address taxpayers' questions. Taxpayer information could be improved, in particular by providing easy access to all changes in laws and regulations through website publication.

\footnotetext{
${ }^{10}$ The authorities have requested technical assistance from the IMF in this area.
} 
Public servants' code of behavior and anti-corruption activity

21. The conduct of government employees is subject to a variety of laws and regulations. Corruption is perceived as a key problem. In recent years, the government has taken a variety of initiatives to combat corruption, which however continues to be perceived by businesses, donors, and others as a key problem. ${ }^{11}$ In general, the code of conduct for civil servants and other government staff is regulated by various laws. ${ }^{12}$ Government officials are obliged to provide every year by January 30 to a special commission a statement of income and property received during the preceding year. ${ }^{13}$ The Center for Combating Economic Crime and Corruption, established in 2002, and a Commission for Combating Corruption in Public Authorities, chaired by the Prime Minister, monitor and enforce proper behavior by public officials. In late 2003 the government adopted an action plan to fight corruption and ensure the rule of law; an interdepartmental task force was established to coordinate its implementation. Special codes of conduct are in place for the tax administration (paragraph 45). Stronger enforcement efforts appear to have been effective in reducing low-level corruption among tax and customs officials over the past 1-2 years.

\section{B. Public Availability of Information}

The coverage and quality of budget documents

22. The State budget covers central government fiscal activities with limitations and provides unconsolidated data on general government. The draft State budget as presented to parliament provides full information on the State budget and EBFs, with the latter presented in separate annexes. Externally-financed investment projects are also presented in a separate annex. In addition, the State budget provides data on transfers from the State budget to the NSIF, the HIF, and local governments. The complete budgets of all regional governments are also provided in an annex, as indicated above. However, the draft State document does not present a fully consolidated account of general government as defined in paragraph 1 . The approved annual budgets of the State, the NSIF, the HIF, and local governments are published in the official gazette, the explanatory notes and background analysis which accompany the draft State budget were published for a while on the MoF's website (Appendix 1). Approved local government budgets are published in local mass media. Over the past few years, the MoF has improved the reporting on budget execution. Monthly narrative summaries of the State budget execution are regularly posted on the government's website ${ }^{14}$ and disclosed in

\footnotetext{
${ }^{11}$ Moldova has tended to score low in comparison with other transition countries in a variety of indices measuring perceptions about corruption and red tape, including Transparency International's corruption perception index and the EBRD's Quality of Governance Index. However, Moldova improved its ranking in the 2003 corruption perception index. See for example http://www.transparency.org .

12 For example, the Law on Public Service, No. 443-XIII/1995.

13 According to the Law on the Declaration and Monitoring of Income and Property of Government Officials, Judges, Prosecutors, Public Servants, and Management Personnel (Nr. 1264-XV/2002).

${ }^{14}$ See http://www.moldova.md/.
} 
mass media. Also, monthly data on the execution of the State, NSIF, HIF, and local government budgets are regularly provided to IMF staff.

23. Defense expenditures are comprehensively reported in the budget and 2.1.1 annual financial accounts. These expenditures are, however, only shown in aggregate form in the annual budget and budget execution reports. They are subject to the same accounting and audit.

Past and forecast fiscal data in the budget

24. The State Budget and the Medium-Term Expenditure Framework 2.1.2 provide sufficient information about the State's main fiscal aggregates for the past and medium term future. The explanatory notes to the annual draft State budget provide actual, revised, and estimated data on the main fiscal aggregates (revenue, expenditure, deficit, financing) of the State budget for up to four years prior to the budget year. ${ }^{15}$ These data are not published together with the approved annual State budget, but available through other publications, including the Medium-Term Expenditure Framework (MTEF) document which also contains forecasts of main aggregates and details for the budget year and two consecutive years (paragraph 33, Box 6).

Budget treatment of off-budget fiscal activity

25. A comprehensive analysis of contingent liabilities has not yet been prepared. The explanatory notes of the draft State budget provide some data on publicly guaranteed external debt, broken down by principal and interest payments, and some reporting is done on energy sector contingent liabilities (Box 3). According to the MoF, no guarantees on domestic and external borrowing by SOEs have been provided over the past five years, and no domestic guarantees currently exist. Neither the State government nor the NSIF report on unfunded pension liabilities. The budget documents do not include a risk analysis, but during the preparation of the 2004-06 MTEF a sensitivity analysis was prepared on the possible impact on government finances of adverse changes in key macroeconomic indicators.

26. Detailed statements on tax expenditures are not reported to the legislature and general public. While the MoF monitors the costs of tax exemptions and informs the government about them, no detailed and regular reporting of tax expenditures is provided for the legislature and the general public. The draft State budget as presented to parliament provides summary data on the costs of tax exemptions, but no systematic and detailed analysis of tax expenditures over time has so far been published. An annex to the draft State budget provides a list of tax exemptions, but without any specification of their costs.

\footnotetext{
${ }^{15}$ More detailed data and graphic illustration (e.g., VAT, direct and indirect revenue trends) are provided for up to five years prior to the budget year.
} 
27. Quasi-fiscal activities are not systematically monitored and their costs are not analyzed and comprehensively and regularly reported. As indicated above, quasi-fiscal activities, especially in the energy sector, have declined in recent years due to reforms in the electricity sector. However, they are still sizable in the gas subsector. Energy tariffs below cost recovery, payment arrears, and other mechanisms were estimated to have resulted in a cautiously estimated quasi-fiscal deficit of 5 percent of GDP in 1999, which was about twice as large as the general government budget deficit in the same year (Box 3). No organization is currently tasked with the responsibility for monitoring and reporting on quasi-fiscal activities, but the government is interested in undertaking more analysis and reporting in this area.

$\underline{\text { Publication of data on debt and financial assets }}$

28. Information on gross public debt is published. Information on domestic and external State government debt is available on a monthly and quarterly basis and can be found on the National Bank of Moldova's website. ${ }^{16}$ The MoF publishes also State debt information, which includes arrears on external debt service payments on a monthly basis. Information regarding domestic State debt is publicly available by type of security, holders (banks and nonbanks), and maturity. As required by the Law on State Debt and State Guarantees, No. 943-XIII/1996, the MoF is legally obliged to record and manage State debt. On a monthly basis, it presents to the government a statement of State debt that contains information on the level and composition of direct and State-guaranteed debt; this is also published in the mass media. The above mentioned law does not oblige the government to report on direct, not-guaranteed debt incurred by SOEs.

29. Information on government financial assets is not yet regularly published, 2.1.4 but has been reported to the IMF and presented to the government and parliament. Information on financial assets, as per requirements of GFS 2001, was provided to the IMF for the first time for inclusion in the 2003 GFS Yearbook. However, these data are not yet published domestically. At the same time, more work is needed to move toward a full balance sheet presentation of government accounts.

\section{Commitment to timely publication of fiscal data}

30. The government is publishing State budget execution data on a monthly 2.2 .1 basis, even though there is no legal requirement to do so. Moldova has $\quad 2.2 .2$ subscribed to the IMF's GDDS. There is no legal requirement to publish fiscal data, but the MoF reports such data on a monthly basis to the government, the legislature, and the general public. Moldova participates in the IMF's General Data Dissemination Standard (GDDS), and aspires to adopt the Special Data Dissemination Standard (SDDS). An interdepartmental regulation approved in 2001 by the NBM, the MoF, and the Statistics and Sociology Department gives guidelines for data publication, including on a data release calendar for the fiscal sector.

\footnotetext{
${ }^{16}$ It is also published in NBM newsletters. Information on auctions of treasury and cash management bills is provided by the NBM to Reuters and Bloomberg services.
} 


\section{Box 3. Energy Sector Quasi-Fiscal Activities and Contingent Liabilities}

Despite recent reforms and improvements, quasi-fiscal activities and contingent liabilities in the energy sector pose substantial fiscal risks for the government, while contributing to large internal and external imbalances. At end-2003, contingent liabilities due to (commercial) external payment arrears on gas deliveries from Russia stood at about $\$ 120$ million, or 6 percent of GDP (excluding interest and penalties, and not considering arrears owed by Transnistria). In addition, there appear to be large domestic contingent liabilities in the form of unpaid bills of SOEs and energy companies. An analysis based on cautious estimates and official data for the electricity and gas subsectors suggested that the quasi-fiscal deficit of the energy sector in 1999 amounted to Mdl 730 million, or 5 percent of GDP. In the same year, the commitment budget deficit of the general government was estimated at 2.5 percent of GDP. As background, Moldova has only limited own energy resources and is therefore largely dependent on imported gas from Russia and electricity from Romania and Ukraine.

Through 1999, energy tariffs were set at levels well below cost recovery, which was a source of quasi-fiscal deficits, combined with widespread privileges for energy consumers and payment arrears. These quasifiscal activities resulted in large overconsumption and waste of energy, while distorting the allocation of resources and adversely affecting the environment. To illustrate the point, in the late 1990s Moldovan citizens consumed on average more than twice as much primary energy than those of Western European countries (see Martin Petri, Günther Taube, and Aleh Tsyvinski; Energy Sector Quasi-Fiscal Activities in the Countries of the Former Soviet Union; IMF Working Paper No. 02/60, 2002). The government has become increasingly aware of these imbalances and problems. It has begun to address them through energy sector reforms, with the help of the World Bank and others. In recent years, key reforms have focused on:

(1) raising energy tariffs to bring them more in line with cost recovery levels (e.g., gas and electricity tariffs were increased by 22 percent and 11 percent, respectively, in mid-2003; a further substantial hike in gas tariffs is currently under discussion). Since 2000, energy tariffs are reviewed annually and approved by the National Energy Regulatory Agency (NERA) on the basis of an officially approved methodology;

(2) enforcing payment discipline by budgetary organizations and increasing budget allocations for energy payments, especially at local government levels. Also, the cash collection ratios appear to have risen in recent years;

(3) privatizing three out of five electricity distribution companies through open tenders to a foreign strategic investor. The new owner has made strong efforts at cutting off consumers who are not paying their bills;

\section{(4) breaking up heating companies as a first step toward privatization;}

(5) replacing previously untargeted implicit energy subsidies to households (estimated at 3.5 percent of GDP in 1999) with better targeted explicit budget subsidies (with costs of 1.5 percent of GDP in 2000) to certain target groups (e.g., pensioners, disabled, large families, war veterans). This "National Compensation Scheme" is financed from the State budget and administered by the NSIF.

As a result of these reforms, payment arrears of households, budgetary organizations, and other consumers to energy providers seem to have declined. However, they are probably still sizable, especially in the gas sector. As part of the quasi-fiscal picture, domestic gas sales are not transparently cross-subsidized by offbudget fees for transit gas.

It would be very useful to prepare a detailed analysis to determine the extent to which quasi-fiscal activities have declined in recent years as a result of the reforms mentioned above. However, so far the government has not undertaken such a systematic analysis, nor does it provide parliament and the general public with a clear assessment of fiscal risks for the State budget related to energy contingent liabilities, which are primarily linked to the quasi-fiscal activities in domestic gas sales. As a result, there appears to be little awareness among politicians and the general public about the extent and costs of these activities. 


\section{Open Budget Preparation, Execution, and Reporting}

The budget preparation process: clarity and consistency of process and presentation

31. The annual budget process is generally open, but the presentation of the budget does not meet international standards, including because of fragmentation. The budget formulation process is fragmented and as a result the State government does not present a fully consolidated general government budget to parliament and the general public. Donor-financed investments, EBF resources of budget organizations, and the NSIF and HIF budgets are not fully integrated for presentational purposes in the National Public Budget. Indicative local government budgets are presented, but not consolidated with the State and other budgets. Given these shortcomings, the State government does not provide a comprehensive and sufficiently detailed view of public revenues and expenditures to parliament and the general public, which hampers effective fiscal management. However, the introduction of the MTEF and other reforms are aimed at eliminating these shortcomings. For example, in the 2004 budget, program classifications have been introduced for selected line ministries as part of a pilot project. The budget classification includes economic, functional, and organizational breakdowns, although these are not fully consistent with GFS standards.

32. The budget process follows a clear timetable. The preparation of the State and other budgets follows a detailed and clear calendar, which is generally adhered to (Box 4). It has been decompressed for the 2005 budget preparation with the objective to allow a better development of sectoral expenditure policies and analytical background work for the MTEF (Box 5). Effectively, the budget process now already starts in January instead of April as was the case before.

The macroeconomic framework and policy basis for the budget

\section{The overall balance of general government as defined by the} framework are the State budget, the NSIF balance, and the overall balance of local governments, as well as the primary balance of the Consolidated Budget. These balances and aggregates are generally monitored on a monthly basis. No comprehensive monitoring of the general government as defined by the GFS and of the financial performance of SOEs and the broader public sector is carried out by the authorities.

\section{Budget forecasts and underlying macroeconomic assumptions are} clearly presented in the draft of the annual budget as presented to parliament. The budget is based on a medium term macro-fiscal framework that is prepared jointly by the Ministry of Economy (MoE), the MoF, and the NBM, with participation of other agencies. The $\mathrm{MoE}$ is the lead agency responsible for macroeconomic forecasts. The supporting materials of the budget documentation also include background papers prepared by the MoE and the NBM, which set out comprehensive and interrelated quantitative macroeconomic parameters and main assumptions underlying the budget. 


\section{Box 4. 2003 Budget Preparation Process in Moldova 1/}

\begin{tabular}{|c|c|c|}
\hline \multicolumn{3}{|c|}{$\begin{array}{l}\text { The fiscal year is set on a calendar-year basis by the Law on Budgetary System and Budgetary Process (1996). The } \\
\text { main steps in the process in } 2003 \text { were as follows: }\end{array}$} \\
\hline Due dates & Activities: State Budget & $\begin{array}{l}\text { Activities: Local } \\
\text { Government Budgets }\end{array}$ \\
\hline March, 20 & $\begin{array}{l}\text { Presentation to Cabinet of MTEF Issues Paper and Budget } \\
\text { Calendar with a preliminary framework. }\end{array}$ & \\
\hline March-April & $\begin{array}{l}\text { Revision and updating of macro-fiscal framework and MTEF; } \\
\text { analysis of cross-cutting issues and preparation of sector } \\
\text { expenditure plans (currently only pilots in } 3 \text { line ministries). }\end{array}$ & \\
\hline May & $\begin{array}{l}\text { Review of the initial MTEF analysis at inter-ministerial } \\
\text { Budget Options Workshop, followed by finalization of the } \\
\text { draft Budget Concept Paper. }\end{array}$ & \\
\hline & $\begin{array}{l}\text { Review and approval of the draft Budget Concept Paper by } \\
\text { Cabinet and issuing of Budget Methodological Notes to line } \\
\text { ministries. }\end{array}$ & $\begin{array}{l}\text { Methodological Notes issued } \\
\text { by MoF to rayons. } \\
\text { Rayons forward the notes to } \\
\text { villages, communes and cities. }\end{array}$ \\
\hline Early June & MoE finalizes macroeconomic forecasts. & \\
\hline & Line ministries submit their budget requests. & $\begin{array}{l}\text { Villages, communes, and } \\
\text { cities prepare draft budgets } \\
\text { submitted to MoF for review. }\end{array}$ \\
\hline $\begin{array}{l}\text { Mid-June to end } \\
\text { July }\end{array}$ & $\begin{array}{l}\text { MoF finalizes macro-fiscal framework. } \\
\text { Budget negotiations between MoF and line Ministries. }\end{array}$ & \\
\hline $\begin{array}{l}\text { Early-mid } \\
\text { August }\end{array}$ & PM/State Chancellery resolves budget disputes. & $\begin{array}{l}\text { Local governments discuss } \\
\text { divergences from the draft } \\
\text { budget with MoF. }\end{array}$ \\
\hline Mid-end August & MoF finalizes draft budget. & \\
\hline October 1 & $\begin{array}{l}\text { Government submits the Draft Annual Budget Law to } \\
\text { Parliament. }\end{array}$ & \\
\hline November 1 & & $\begin{array}{l}\text { Villages, communes, and } \\
\text { cities revise and submit draft } \\
\text { budgets to local councils for } \\
\text { approval. }\end{array}$ \\
\hline November 15 & & $\begin{array}{l}\text { Rayons' budgets submitted to } \\
\text { rayon councils for approval. }\end{array}$ \\
\hline December 5 & Parliament approves the state budget. & \\
\hline December 10 & & $\begin{array}{l}\text { Village, commune and city } \\
\text { councils approve their } \\
\text { budgets. }\end{array}$ \\
\hline December 20 & & $\begin{array}{l}\text { Rayon councils approve rayon } \\
\text { budgets. }\end{array}$ \\
\hline
\end{tabular}




\section{Box 5. Summary of the 2004 Budget Calendar*}

The following changes to the budget calendar in Moldova are currently planned for the preparation of the 20052007 MTEF and the 2005 annual budget:

- January-February. Preparation of the Macro-fiscal framework.

- February. Analysis of cross-cutting expenditure issues.

- February-March. Analysis and preparation of sector (strategic) expenditure plans (currently only pilots in 3 line ministries).

- March-early April. Finalization of expenditure plans and resource ceilings.

- $\quad$ Late April—mid August. Finalization of draft annual budget to present to government on August, 15.

* Source: MoF (Government Decision No. 1631/2003).

\section{External scrutiny of macroeconomic models and assumptions is .}

encouraged. Macroeconomic forecasts and models are discussed during budget preparation in a forum consisting of the MoE, the MoF, the NBM, the Department of Statistics and Sociology, local governments, trade unions, employers' associations, and the National Institute of Economics and Information Technology. The macroeconomic forecasts are published as part of the State budget. ${ }^{17}$ The macroeconomic model used by the MoF for analysis and forecasting is under development. The MoE prepares its macroeconomic forecasts on the basis of a different model. The reliability of official macroeconomic forecasts has improved in recent years, but continues to be optimistic in some areas (e.g., inflation, GDP growth, privatization proceeds, external grants and loans).

$\underline{\text { Medium-term planning and analysis of fiscal risks }}$

\section{A statement on fiscal policy objectives is reflected in the Medium Term} Expenditure Framework (MTEF) and the annual State budget. The draft annual State budget contains a broad summary statement of the government's fiscal objectives, which are outlined in greater detail in the MTEF. The development of the MTEF aims at creating a stable framework to guide the annual budget process. The authorities began in 2002 with the preparation of their first MTEF (2003-05). Following the establishment of an institutional framework, the 2004-06 MTEF was prepared in the first half of 2003 and subsequently used as a basis for the preparation of the 2004 budget (Box 6). So far, MTEFs have been approved by the government, but not submitted for discussion and approval to parliament. However, the authorities intend to present the 2005-07 MTEF together with the annual budget to parliament for discussion.

${ }^{17}$ See the MoF's website (www.moldova.md). 
37. Fiscal rules are formulated and enforced for the State government

balance and local government finances. The organic budget law prescribes that the State budget should be balanced, but it allows the incurrence of a deficit if foreign financing is available. It also stipulates that no central bank financing of the budget through money creation is permitted. The annual budget law specifies nominal limits for external and domestic debt that can be assumed during the budget year. The Law on Local Public Finance stipulates that local government budgets must be balanced, while prescribing strict borrowing limits (paragraph 11, Box 2).

38. Estimates of new initiatives and ongoing costs of government policies $\quad 3.1 .4$ are generally provided in the annual budget documents, but not always clearly distinguished. New policy initiatives are generally described and aggregate cost estimates are provided in the draft annual State budget and its explanatory notes. As regards wage policies, the 2004 draft budget included a large wage reserve fund. Following parliamentary and public debate, wage rises were determined and the wage fund was allocated across sectors in the final budget.

\section{Fiscal sustainability issues and the sensitivity of budget estimates to} changes in macroeconomic parameters are not discussed in the budget documentation for the draft annual State budget, but considered in the MTEF. The 2004-06 MTEF includes an analysis and graphic presentation of debt dynamics and debt sustainability indicators, including State debt as a share of GDP and the State debt service relative to revenue (Box 6).

$\underline{\text { Clarity of control of budget execution }}$

40. Basic accounting and internal control procedures are in place, but existing laws and regulations are cumbersome, hampering implementation. The accounting functions in line ministries are performed by dedicated units which are responsible for accounting for, reporting on and controlling budgeted expenditures, according to the Accounting Law No. 426-XIII/1995, and relevant instructions and guidelines. The accounts of ministries and departments are primarily maintained on a modified cash basis, but gradually being expanded to accrual accounting. Individual ministries already maintain a commitment registration system. The NSIF keeps records on an accrual basis. The treasury system consists of a two-tier structure, including the central treasury (State treasury) and a network of 37 regional offices (territorial treasuries) that are subordinated to the State treasury. The State treasury became operational in 1997; it is responsible for executing the State budget. ${ }^{18}$ All fiscal operations of local governments are conducted through territorial treasuries since 2001.

\section{Reports on revenue and expenditure arrears are prepared as part of the} monthly reports submitted to government. Reports on revenue payment arrears are

\footnotetext{
18 The central treasury is organized around a single treasury account maintained at the NB where all central government revenues are collected and government operations are recorded. Several additional accounts in various foreign currencies are maintained at NBM, as well as a separate account for the revenues of the State Social Insurance Budget.
} 
prepared and submitted on a monthly basis by the State Tax Inspectorate for the government, including a list of the 100 taxpayers with the largest arrears. With regard to expenditure arrears, aggregate monthly reports as well as more detailed quarterly reports are available. This reporting provides for an assessment of arrears and allows their monitoring, including the breakdown of arrears between current spending (wages, goods and services) and capital outlays. Aggregate data on both revenue and expenditure arrears are provided to the government and parliament and included in the budget documentation

42. Financial management practices are generally not well coordinated. 3.3.1/2.1.4 Uncertainty about cash availability has caused great problems in budget execution in the past and as a result line ministries accumulated large payment arrears. The intention of the creation of a cash management unit in MoF in 2001 was to improve the situation, but some weaknesses remain. The linkage between cash and debt management is also weak but should improve over time as the newly established debt management unit in MoF becomes fully operational. The authorities are currently reviewing their domestic and external debt management strategy, with the objective to restructure external debt and avoid further accumulation of external debt payment arrears. Information on domestic and external debt is available by issuance, types of holders and instruments, and maturity.

\section{Box 6. The Medium-Term Expenditure Framework}

Over the past few years, the MoF has intensified efforts to develop a medium-term budget framework, focusing in particular on medium-term expenditure projections that are consistent with the medium-term macroeconomic framework. With assistance from the World Bank and DFID, this has culminated in the preparation of two consecutive medium-term expenditure frameworks (MTEFs) for the periods 2003-05 and 2004-06. Various institutions are represented in a task force that prepares the MTEF. The task force is chaired by the MoF, and includes representatives of the MoE, line ministries, other government organizations, local government, as well as leaders of labor unions and employers.

The latest framework, published in September 2003, is of commendable quality in terms of providing detailed and comprehensive analysis of government finances beyond the State budget (e.g., coverage of the NSIF and local governments). For the first time, annexes with strategic medium-term expenditure plans for three priority sectors (education, health, and social assistance) were prepared. While these are still mostly qualitative in nature, the authorities intend to provide more detailed, program-based quantitative projections for these three sectors in the 2005-07 MTEF. This will allow integrating the budget projections with the PRSP process, linking costed programs with input and output indicators (e.g., student-pupil ratio, higher enrolment) as well as poverty alleviation goals (e.g., increased literacy rate).

The 2004-06 MTEF also includes a debt sustainability analysis, which presents indicators such as government debt as a share of GDP and the debt service relative to revenue. The MTEF projects that government debt will decline to 44 percent of GDP in 2006. There is also recognition of the heavy cash flow burden posed by the debt service in 2004 and 2005. In this context, it emphasized the need to maintain broad balance in the general government accounts throughout 2006. However, the analysis does not consider (energy sector) contingent liabilities that may become explicit during this period.

The authorities intend to cut income tax rates further over the medium term. These could pose a risk to the projected medium-term revenue projections, which could be analyzed. While the impact of fiscal risks arising from possible adverse interest rates and/or exchange rate shocks was considered in a "pessimistic scenario" during the 2004-06 MTEF preparation, the results of this scenario were not reported in the final document as it was feared that this could be interpreted as a negative signal by the general public. 
43. Internal audit focuses primarily on financial control. Internal audit is carried out independently by each line ministry and government department. Pertaining legislation is complex, and actual practices emphasize financial control. Internal systems for ex-ante and ex-post audit could be strengthened. The government is currently working on the development of a new conceptual framework and law on internal audit.

44. Procurement rules and practices are generally clear and well-known, 3.3.2 but some strengthening would be useful to further improve transparency. The Law on Procurement of Goods, Works, and Services, No.1166-XII/1997, and procurement regulations set out the procurement procedures for the government. According to this law, open tender procedures should be followed and the process is overseen by the central state procurement agency (National Agency for Government Procurement). Further strengthening of the procurement process could be undertaken by tightening further rule on discretion by public officials in awarding contracts and in reviewing protests lodged by unsuccessful bidders.

\section{A complex set of laws and regulations determines government} employment and pay. Employment procedures, rights, and duties of government and public sector staff are governed by the general Labor Code, the Public Service Law, and the Remuneration Law. These are supported by sector-specific regulations and collective bargaining agreements. A draft law is being prepared which intends to establish a more rule-based and performance oriented remuneration system for government staff.

Clarity of internal control and independence of tax administration

46. Internal monitoring and control functions in tax and customs administrations are carried out by specific departments. The internal departments of internal security in tax and customs administrations collect information about tax officers and internally investigate alleged illegal actions performed while on duty. The internal control functions of both tax and customs administrations are separate from similar departments in other government agencies, and the emphasis is primarily on proper accounting and the detection of corruption (see also paragraph 42).

47. Tax and customs administration officials are formally given legal 3.3.4 protection from political interference. While the STI is a legal entity within the Ministry of Finance, the customs administration reports directly to the government. The relevant laws formally guarantee protection from political interference.

Accounting and reporting on budget execution

48. The accounting system is capable of producing accurate in-year 3.3 .1 reports on central government budget outturn. These reports are available on a monthly and quarterly basis. Monthly reports are usually produced within one month after the end of month. These reports include data on payment arrears. There is separate reporting on transactions in physical and value terms (e.g., humanitarian assistance). The chart of accounts is based on GFS 1986; it would require adjustments to fully conform with GFS 2001. 
49. Fiscal reporting does not cover general government fully and

$3.3 .1 / 2.1 .1$

uniformly. Budget execution reports on the various components of general government as defined by the GFS are available in high frequency, but these are not consolidated in a general government table format. Also, data is not presented to the general public and others in a uniform way. This is partly due to the lack of coordination between the MoF and the NSIF in data aggregation; for example, the NSIF only reports data on a quarterly basis to the MoF (in hard copy). This problem is compounded by the use of different accounting systems as the NSIF uses accrual accounting and by the practice that the NSIF, and the newly established HIF, operate outside the State treasury system.

50. The legislature does receive timely in-year reports on budget outturn, $\quad 3.4 .1$ but does not undertake a formal mid-year review. Reports on monthly execution of the budget is made available to the public in the form of brief communiqués, however these reports are mainly narrative and limited in their scope and analysis. In accordance with the GDDS, information on budget execution is published quarterly on a website and in the Statistical Bulletin.

51. The final audited annual accounts of the State budget are available $\quad 3.4 .2$ within four months of the end of the fiscal year. The final accounts submitted to the parliament incorporate the central government budget, extrabudgetary funds, summary of received foreign credits and grants for investment projects, and summary of administrative territorial units' budgets. At the same time, activities funded by credits and grants for investment projects not included in the treasury system are incorporated in the reporting in aggregate. Under the Law on Local Public Finance, reports on the execution of the budgets of local governments are approved by the local representative bodies before February 15 of the following year.

Results-oriented budgeting and reporting

52. The objectives and expected results from government activities are discussed in general terms in the draft annual budget and the annual budget execution report submitted to government and the Parliament. The draft annual budget and the annual budget execution report provide in general terms information on envisaged and achieved results from government activities. In 2003, a program-based budget presentation was partially introduced with the objective to improve the efficiency of program implementation.

\section{Assurances of Integrity}

$\underline{\text { Integrity of data processes }}$

53. Budget projections are moderately reliable and the variance between budgeted and actual outturn of main fiscal aggregates is disclosed. Revenue and expenditure projections are generally quite reliable, but there is a tendency to make optimistic assumptions on some variables (e.g., external grants and loans, privatization proceeds). Prior to 2003, unrealistic GDP growth projections resulted in overly optimistic revenue estimates for the budget. The difference between planned and actual outturn for revenues, expenditures and the overall State budget balance for 2003 was disclosed to the general 
public through website publication. Supplementary budgets are usually prepared twice per year. Data on the use of the Reserve Fund are included in budget execution reports.

54. Statements on accounting policy are included in the budget and final $\quad 4.1 .2$ accounts documents. Budget transactions are recorded on cash basis. Methodological norms as set out in the "Instructions on Accounting in spending organizations" are applied to accounting of the cash execution as well as accrual accounting of the State budget, and to cash accounting of the budgets of administrative local government units in the treasury system. The MoF is responsible for setting accounting policies and standards, and for enforcing compliance with established accounting standards.

55. The process of accounts reconciliation and fiscal reporting are mostly $\quad 4.1 .3$ effective. Crosschecks of internal consistency of fiscal data are undertaken on a regular basis, as well as preliminary crosschecks of this data. All treasury transactions are executed at the single bank account for each budget. This allows for reconciliation of information on treasury transactions with banking system. The NBM also undertakes a reconciliation of the monetary and fiscal accounts. Data reconciliations are shown explicitly in the annual reports on budget execution to parliament and the general public.

$\underline{\text { Independent oversight }}$

56. External audit is independent of the executive branch and its mandate .does cover all public sector activities. The Law on the Court of Accounts, No. 312-XIII/1994, created the Court of Accounts (COA) as supreme audit institution in Moldova and stipulates its independence. The Head of the COA is appointed by parliament. The mandate of the COA is wide ranging - COA is free to audit any public body or institution. In practice the COA is understaffed which hinders its effectiveness. The COA generally publishes its reports in the Official Monitor and provides annual reports to parliament.

57. Strengthening of both internal and external audit capacity is required

The COA has 70 auditors working at the central government, and another 70 staff covering the local government institutions. This does not allow for regular auditing of all public institutions. The COA fully relies on the State budget for funding of its operations. As discussed above, capacity of the internal audit function could be strengthened.

58. The legislature discusses external audit reports, but follow-up is effectively limited to law enforcement agencies. Reports of the Court of Accounts are generally received and reviewed by parliament; however, there have been cases in the past in which special audit reports have not been shared with parliament. Follow-up on the findings of audit reports is generally limited to law enforcement agencies.

59. The national statistics office is given legislative assurance of 4.2 .3 independence. According to the Law on Statistics 412-XII/1990, with subsequent amendments and addenda, the Department of Statistics and Sociology is in charge of the collection and dissemination of data received from other agencies, including fiscal data. The office is technically independent. A draft statistics law, which will strengthen the independence of the office further, is currently under discussion. 


\section{IMF STAFF COMMENTARY}

60. Moldova has made progress in recent years in improving fiscal transparency and meets the requirements of the fiscal transparency code in a number of areas. The roles and responsibilities between the executive, legislative, and judiciary, as well as between different parts of government are relatively clearly defined. Government operations are well distinguished from the activities of the central bank, and in most cases also from activities of the financial sector. The coordination mechanisms between budget and off-budget activities are reasonably well defined. Reporting on the budget to parliament and the general public has strengthened in recent years, but a number of shortcomings in this area remain (see below). Consolidating all tax legislation into two organic codes (domestic taxes and customs) has improved the transparency in taxation, albeit there remains scope for further improvement.

61. The quality of budget preparation has improved considerably due to the introduction of medium-term expenditure frameworks (MTEFs). The MoF has made commendable progress during the past few years in preparing MTEFs. In particular, the 2004-06 framework is of considerable analytical depth and breadth. The annual budget calendar, which is clear and generally adhered to, has been amended to allow a better integration of the preparation of the MTEF into the annual budget cycle.

62. In several areas, Moldova meets fiscal transparency requirements to some extent, but further improvements would be useful. These areas include budget consolidation and reporting, taxation, coordination with local governments, the treasury, and internal and external audit. The budgets of EBFs, the NSIF, the HIF, and donor-financed projects are not yet well consolidated with the State and local government budgets as part of general government. Transparency could also be improved further by undertaking more analytical work, for example on tax expenditures, which should be published. While quasi-fiscal activities in the energy sector have declined due to electricity sector reforms, they remain sizable, particularly related to gas, which warrants more intensive monitoring and analysis. In tax policy and administration, the authorities should refrain from frequent within-year changes, and all changes to laws and regulations should become more easily available to the general public, including through website publication. Financial relations between the State and local governments need to be put on a sounder and more permanent footing, following more intensive consultations with local government representatives and independent experts. These consultations should address concerns about declining autonomy of local governments. Modernizing and consolidating treasury operations is a matter of urgency, as are reforms in internal control and external audit.

63. Transparency appears to have stagnated, or even declined, in a few areas in recent years. The government continues to control the activities of economic agents through a variety of mechanisms and channels, some of which are not transparent. For example, the former financial guards continues to operate independently of tax and customs administrations, and its role under the newly established Center for Combating Corruption and Economic Crime does not appear to be based on well-defined, formal rules. A number of informal measures have been introduced in recent years that hamper free international trade and economic growth, while making the regulatory environment more complex and less transparent. The monitoring of financial operations of SOEs 
deserves greater attention and scrutiny. Currently, the MoF as the key fiscal agency of the government plays no role in the monitoring of financial operations of SOEs, nor does any other central government agency monitors SOE finances comprehensively and systematically.

\section{Against this background, the following recommendations are of high priority:}

\section{Budget preparation, presentation, and reporting}

- Establish a reporting mechanism involving project implementation units and line ministries that would allow the MoF to consolidate data on donor disbursements and expenditures made by foreign-financed projects, and include these data in a consolidated manner in the monthly reports to the government, parliament, and the general public.

- Integrate donor-financed investment project spending progressively into the Treasury accounting, starting this process as soon as possible with the proposed World Bank pilot project.

- Revise the organic budget law to reflect changes in the budget calendar, the MTEF process, fiscal data reporting practices, and fiscal data compilation and reporting on general government.

- Present to parliament and the general public together with the draft State budget a fully consolidated budget for the general government, and report budget execution to parliament and the general public on a consolidated general government basis.

- To improve reporting on budget execution for the general public, introduce a standard summary table to report monthly fiscal data on a general government basis together with a narrative summary.

- Present central and local government expenditure data in the annual draft budget, the MTEF, and in monthly budget execution reports separately in economic and functional classification.

- Prepare for the annual draft budget, or independently at least once per year, a tax expenditure analysis covering the major taxes and highlighting the 10 largest tax exemptions and concessions.

\section{Clarifying responsibilities and coordination}

- Intensify regular consultations with local governments and independent experts, with the objective to establish a sounder and more permanent system for revenue sharing and expenditure transfer formulae. In this context, review responsibilities for decision-making authority on tax policy, especially tax concessions, that affect the revenue base of local governments.

- Eliminate as many EBFs as possible and consolidate them with mainstream line ministry activities. 
- Place customs administration under the supervision of the MoF to strengthen its role in tax policy and administration and to improve cooperation on key inter-departmental issues (e.g., VAT refunds) and the exchange of information.

- Revise VAT refunds regulations in line with IMF technical assistance advice.

- Streamline responsibilities in the privatization process for non-strategic SOEs between the Privatization Department, line ministries, and others.

$\underline{\text { State-owned enterprises and quasi-fiscal activities }}$

- Strengthen the monitoring of financial operations of SOEs, for example by requiring line ministries to provide to the government (1) draft annual financial plans for SOEs for review and approval, and (2) quarterly reports on SOE financial performance.

- Make SOEs subject to external audits of annual accounts, and make the audit reports available to parliament.

- Systematically and regularly review public asset ownership with a view to determine clear guidelines on corporatization, privatization, or liquidation.

- Publish all informal regulations on international trade of specific products.

- Analyze contingent liabilities and quasi-fiscal activities in the energy sector and disclose results of this analysis and policy recommendations to parliament and the general public, either as part of the draft budget or separately. Such analyses will help informing debates on strategies for further reforms, including the design of safety nets to help low-income households coping with increases in energy tariffs.

\section{$\underline{\text { Public sector accounting and oversight }}$}

- Limit the focus of the Center for Combating Corruption and Economic Crime to the investigation of corruption by public sector officials, leaving all tax enforcement activities to the tax and customs administrations. Also, consider placing the supervision of the Center under the control of parliament rather than the government, and have the director of the Center be appointed by parliament rather than the government.

- Review the inspections regime with a view to streamline it, which will also help reducing opportunities for corruption.

- Strengthen external audit and publish all external audit reports on websites and in hard copy. Present regular annual reports of general findings of external audits to the government, parliament, and the general public.

- Modernize internal control operations in line ministries and other government agencies, including through training and technical assistance. 
- Continue to strengthen anti-corruption activities. Reduce tax exemptions and concessions further will help limiting opportunities for corruption.

- Strengthen local government treasuries and include donor-financed projects as well as NSIF and HIF operations in the State treasury operations. Considering current capacity constraints, implementing this recommendation may require further technical assistance.

\section{Other recommendations:}

- Clarify and enforce the fiscal rule on the State budget by avoiding reference to a balanced budget, since the law does allow the incurrence of budget deficits and its financing through foreign and domestic borrowing.

- Better integrate the preparation of the MTEF with that of the annual budget to ensure use of the same macroeconomic and financing assumptions in both frameworks.

- Strengthen accounting and audit standards for SOEs, and publish audited annual accounts.

- Implement a fully-integrated financial management information system (IFMIS) for the State and local treasuries.

- Improve coordination between cash and debt management functions in the State of local treasuries. 


\section{Appendix 1. Public Availability of Information-A Summary}

\begin{tabular}{|c|c|c|c|c|}
\hline Budget and Fiscal Report Element & Included in budget/report documents & $\begin{array}{c}\text { Available to } \\
\text { the public }\end{array}$ & Para. Ref. & Code Ref. \\
\hline $\begin{array}{l}\text { III. Central government (CG) budget } \\
\text { estimates }\end{array}$ & $\begin{array}{l}\text { Yes. While not published together with the approved State } \\
\text { budget, it is available from other publications, including the } \\
\text { Medium-Term Expenditure Framework (MTEF). }\end{array}$ & Yes & $\begin{array}{l}21,23 \\
30-33\end{array}$ & 2.1 .1 \\
\hline IV. CG Defense Expenditures & $\begin{array}{l}\text { Yes. But only shown in aggregate form in the annual budget } \\
\text { and budget execution reports. }\end{array}$ & Yes & 22 & 2.1 .1 \\
\hline V. CG EBFs & $\begin{array}{l}\text { Yes. Published together with the annual State budget in } \\
\text { separate annexes. }\end{array}$ & Yes & $1,13,21$ & 2.1 .1 \\
\hline VI. CG Budget outturns & $\begin{array}{l}\text { Yes. The difference between planned and actual outturn for } \\
2003 \text { was disclosed to the public (website publication). }\end{array}$ & Yes & 52 & 2.1 .2 \\
\hline VII. CG Budget forecasts & $\begin{array}{l}\text { Yes. Not published together with the annual budget, but } \\
\text { available from other publications, including the Medium- } \\
\text { Term Expenditure Framework (MTEF). }\end{array}$ & Yes & $21,32,33$ & 2.1 .2 \\
\hline VIII. CG Contingent liabilities & $\begin{array}{l}\text { No systematic analysis and reporting has so far been } \\
\text { prepared. However, the explanatory notes of the draft State } \\
\text { budget provide data on publicly guaranteed external debt, } \\
\text { broken down by principal and interests. }\end{array}$ & No & $\begin{array}{l}24, \text { Box } 3 \\
\text { Box } 6 .\end{array}$ & 2.1 .3 \\
\hline IX. CG Tax Expenditures & $\begin{array}{l}\text { No detailed and systematic analysis of tax expenditures over } \\
\text { time has so far been published. An annex to the draft State } \\
\text { budget provides an exhaustive list of tax exemptions. }\end{array}$ & No & 17,25 & 2.1 .3 \\
\hline X. CG QFAs & $\begin{array}{l}\text { No. Quasi-fiscal activities are not systematically monitored } \\
\text { and their costs are not analyzed and comprehensively and } \\
\text { regularly reported to the government and the general public. }\end{array}$ & No & $\begin{array}{l}4,9,26 \\
\text { Box } 3\end{array}$ & 2.1 .3 \\
\hline XI. Macroeconomic assumptions & $\begin{array}{l}\text { Yes. Budget forecasts and underlying macroeconomic } \\
\text { assumptions are clearly presented in the draft of the annual } \\
\text { budget presented to parliament and in the MTEF document. }\end{array}$ & Yes & 33 , Box 6 & 3.1 .3 \\
\hline $\begin{array}{l}\text { XII. Analysis of fiscal risks/sensitivity } \\
\text { analysis }\end{array}$ & $\begin{array}{l}\text { No. Sensitivity analysis for macroeconomic assumptions } \\
\text { were prepared for MTEF, but not published. }\end{array}$ & No & Box 6 & 3.1 .5 \\
\hline
\end{tabular}




\begin{tabular}{|c|c|c|c|c|}
\hline Budget and Fiscal Report Element & Included in budget/report documents & $\begin{array}{c}\text { Available to } \\
\text { the public }\end{array}$ & Para. Ref. & Code Ref. \\
\hline XIII. CG Debt & $\begin{array}{l}\text { Yes. Information on State debt is available on a monthly basis. } \\
\text { The MoF periodically presents to the government, parliament, } \\
\text { and public a statement of public debt, with composition of public } \\
\text { and publicly guaranteed debt. }\end{array}$ & Yes & 27 & 2.1 .4 \\
\hline XIV. CG Financial Assets & $\begin{array}{l}\text { Yes. Information on State financial assets is not regularly } \\
\text { published, but was reported to IMF recently. }\end{array}$ & Yes & 28 & 2.1 .4 \\
\hline XV.Sustainability Analysis & $\begin{array}{l}\text { Yes. Fiscal sustainability indicators are not discussed in the } \\
\text { annual budgets, but considered as part of the MTEF process. This } \\
\text { analysis, however, only covers the State level. }\end{array}$ & Yes & 38, Box 6 & 3.1 .1 \\
\hline $\begin{array}{l}\text { XVI. General government budget } \\
\text { estimates }\end{array}$ & $\begin{array}{l}\text { Yes. General government accounts are not discussed in the } \\
\text { annual budgets; the MTEF presents medium-term projections, } \\
\text { broken down by the Consolidated Budget, the NSIF, externally- } \\
\text { financed projects, and EBFs. }\end{array}$ & Yes & 21, Box 6 & 2.1 .5 \\
\hline $\begin{array}{l}\text { XVII. CG Monthly/quarterly reports on } \\
\text { fiscal outturn }\end{array}$ & $\begin{array}{l}\text { Yes. Reports on monthly execution of the budget are made } \\
\text { available to parliament and to the public in a timely way. }\end{array}$ & Yes & 48 & 3.4 .1 \\
\hline $\begin{array}{l}\text { XVIII. General government } \\
\text { Monthly/quarterly reports on fiscal } \\
\text { outturn }\end{array}$ & $\begin{array}{l}\text { No. Fiscal reporting does not cover all parts of general } \\
\text { government in a systematic and consolidated manner. Although } \\
\text { in-year reports on the various components of general government } \\
\text { are available in high frequency, these are not consolidated and } \\
\text { presented in a uniform way. }\end{array}$ & No & 48 & 3.4 .1 \\
\hline $\begin{array}{ll}\text { XIX. } & \text { CG final accounts }\end{array}$ & $\begin{array}{l}\text { Yes. The audited final accounts of the State budget are available } \\
\text { and presented to parliament within four months of the end of the } \\
\text { fiscal year. }\end{array}$ & Yes & 50 & 3.4 .2 \\
\hline XX. General government final accounts & No. & No & 50 & 3.4 .2 \\
\hline
\end{tabular}

